\title{
The Dialectics of Media, Culture and Violence: An Analytical Study
}

\author{
Ashes Kr. Nayak \\ Ph.D Scholar, Assam University
}

\begin{abstract}
In the recent times, conflicts and violence are regular phenomena in every society. Such conditions often raise questions over the general practices of media and its consequences on socio-cultural practice. It necessitates the need for a dialectical-inquiry of media, culture and violence to arrive at the points of their intersection. While media encourages the culture of modernity, it fails to create a condition for the culture of modernity to prevail and persist. Over the last few years, News-Media, especially Television, in the NorthEastern part of India has extended its reach and operation. It is quite an observable fact that along with the growth of $24 \times 7$ News Televisions, the rate of violence-especially petty violence-in North-East, particularly in the state of Assam has gone up. The culture of violence on television has a multiplier effect. With its regular subscription to violent images, TV news media has badly affected the social practice and human conduct leading to 'media-violence' and 'social-violence'. The July 9, 2012 incident of the molestation of a teenage girl in Guwahati, and its violent projections in one of the regional News TV (News Live) is one among the many events that leaves ethical-vacuum both in media practice and social practice. Following the incident, reactions from media, intellectuals, NGOs, statutory bodies and the state have brought some ethical questions to the floor. In this backdrop, the paper interrogates the inevitable association between media practice and social practice, and experiments with Non-violence as a code-of-conduct for maintaining cultural unity and cultural purity.

Keywords: Dialectical inquiry, Media violence, Social violence, Culture of violence
\end{abstract}

\section{Introduction}

The world is experiencing a tendency of conflict in socio-economic, political and cultural spheres where we are caught between the high promises of modernity and the severity of tradition along with the dogmatism of religion, race, caste, and gender. Though the struggles over such conflicting identities are not new as such, they have obtained new status and positions. Reason for such a phenomenon the world over is often related to globalisation led by a revolution in communication and media technologies. Instant flow of images, ideas and cultures with the help of new communication technology has brought disjuncture in the social and cultural conditions across the world not to exclude India. It has led to what Lefebvre (1991) terms it a 'contradictory space'. Further, to cite Appadurai (1990) “...[T]oday's global interactions is the tension between cultural homogenization and cultural heterogenisation" (Appadurai, 1990, p.295) which is more virulent in the network age and communication. Such an ambivalence tendency is also experienced in national and regional spheres in India often in the name of unity and diversity, nationality, ethnicity, and many other unifying modernist projects. Not only that, capitalism, with its utopian promise for autonomy, freedom, and choice, has led to the construction of a more disjunctive and conflicting social and cultural space.

The conflicts or chaos or contradictions we experience are both ideological and material. Media, as the prophet of modernity has certainly bridged the difference between local and global as it was proclaimed by Marshall McLuhan (McLuhan 1964, 1994), facilitating transnational and transactional flow of information, ideas and people (Appadurai, 1990), and leading to an interexchange of culture, political values and economic benefits among nations, regions and localities. But it seems, media has failed in its effort to create a condition for modernity to flourish in many parts of the world including India that has led to a shift in the over all ways of thinking and living experienced through a postmodern condition. Though the modernist projects have succeeded in objectifying the world, they lags behind in fostering change within the minds of the masses to act in response to the emerging conditions which is further reflected in social practices and media practices - resulting either in social-violence or media-violence - as it is evident in the increasing number of conflicts, violence, revolutions that pervades the globe. Starting from the string of uprisings in the Arab world against monarchical regimes to the anticorruption movement in India against a defunct democracy or the women's movement demanding equal rights and access to secure social space or to LGBT (Lesbian Gay Bisexual Transgender) community's protests marches for their sexual rights, all the events require a critical understanding to arrive at the complex matrix of media, culture and violence.

Both media and society as foreseen by Herbert Marcuse (1964) have become one-dimensional in character emphasising only the objective reality, ignoring the subjective attributes and creating an ethical 
vacuum. Along the lines, media has also reduced the difference between time and space, creating a world of illusion, turning everything into real and immediate and multiplying the pace of change often driven by conflicts or contradictions. A similar tendency is perceptible in the regional and national sphere in India, where there is a movement of people from periphery to centre and at the same time there is a movement from the centre to the periphery. There are people who are coming closer to the centre of power, politics and economy breaking the long existing prejudices of caste, religion, gender - often backed by inclusive policies. At the same time, there is a sense of alienation and separation of certain sections from the mainstream. For instance, we can talk here of the over representation and exaggeration of issues related to women empowerment and their increasing access to social space and counter reactionary incidents culminating in violence against women and other vulnerable sections. It has generated heated debates in the media, academia and policy discourse. Such changes have led to a diverse and cosmopolitan character of the material or representational spaces where we live, work, and entertain ourselves. Such diversities often create new challenges both for media and society to act with restraint.

The reconfiguration of the material space has not been adequately supported by the subjective domains, and what emerges out of such disunity are opposing tendencies of dominance or resistance, acceptance or rejection, autonomy or dependence, emancipation or control, enlightenment or deception, division or unification, individualism or pluralism, culture or anarchy, unity or diversity; like many other phenomena that are self contradictory in nature. Such contradictory and critical processes of change or dialectical progress of the world raises question over the language we practice for our engagement with the material space. Media as a force of production - as argued by Williams (1993) — is often challenged by these contradictions and oppositional tendencies, and drives itself into confusion whether to act in line with its predefined objectivities or with a subjective interference. In this critical situation should we practice the language of 'nonviolence' instead of a violent form language that has long been the order of social and media discourse? Because it is possible only through nonviolence, to bring unity among the new and emerging subjects and objects. Can we think of 'nonviolence' as a dialectical principle or principle of change? Or can we consider nonviolence as a dialectical mechanism for subjective-objective unity?

Comparatively, media has a much broader dimension than how it is generally understood. Similarly, the word culture has wider connotations than how it is perceived and practiced. Raymond Williams (1958, 1993) in Culture and Society defines culture, 'a general state or habit of the mind', having close relationship with the idea of human perfection. He also defines culture as 'a whole way of life, material, intellectual and spiritual'. Both culture and communication are forces of production that produces a particular form or condition of life. However, media as a force of production has promoted and appreciated a material culture ignoring the subjective dimensions and expanding the gap between mind and matter further alienating the subjects from the objects that has often led to a culture of violence. Culture has never been a static condition, but a continuously evolving phenomenon. Along with the invention of new technologies and communication, and their adaptation in our routine life it has given birth to a new kind of media-culture. Further, it is culture, which decides the way we engage ourselves with space and time that further determines our identity, existence or meaning of life. Culture has two aspects, one is cognitive and the other is material. Cognitive culture is subjective in nature and constitutes our ideas and thoughts, where as the material culture constitutes of our engagement with objective world. Culture is also consciousness that constructs a form of life or a concrete formulation, i.e. society. Social practices are often determined by culture, and in a hyper-mediated society culture is determined by media as a new form of consciousness which is seen often violent in nature. The noticeable fact is that both media and culture have encouraged a violent form of life resorting to violence in their general practices. In such a situation the question that arises is what should be the language of 'media' as a dialectical force. What would be the language of 'dialectic' as a force of change that has evolved over a long period of history, escaping itself from the prejudice of materialism and idealism? So far it seems that media has produced a violent form of consciousness along with a violent form of life. This has created our need for an experiment with nonviolence that would sustain socio-cultural unity.

\section{Theoretical framework}

If we do a philosophical enquiry, we find that just like the base-superstructure metaphor, it is often contradictory; whether socio-cultural practice determines media practices or media practice is determined by the socio-cultural practices. The debate over such a contradictory process of evolution or revolution has been longstanding since the time of ancient philosophy to modern. Such a process of evolution known as 'dialectics', and its philosophy 'dialectical philosophy', is divided into two branches; one is 'dialectical idealism' that gives priority to ideas over matters and the other is 'dialectical materialism', which gives priority to matter over ideas. If we look at the recent incident of harassment of the girl (that took place in Guwahati on July 9, 2012) through a dialectical lance, one view that comes to the fore is that it is social practice that is determining the media practices, that subscribes to the Marxist idea "it is not consciousness that makes a man social being, rather it is social being that makes a man conscious". Further, if we take an idealistic turn, and consider that the media has 
replaced human consciousness in a hyper-mediated society, the other view that comes out to the fore is that it is media practice that is determining social practices as it has happened in the incident of Bodo-Muslim clash in Assam with its fall outs to other parts of the country. It seems the confusion over media practice and social practice is just like the long existing confusion between idealism and materialism. Further, it can be mentioned here that presently we are experiencing a post-modern and disjunctive space through a modernist subject which is at the core of such violent and revolutionary tendencies.

The subject-object imbalance or disunity,- - which is the cause of conflicting tendencies and violencethe dialectical philosophy has been trying to determine since years lies in the irrational the growth of science, society and language. In the process of evolution each of these phenomena has influenced the other. While on the one hand, substantial amount of research has been conducted for the growth and development of the philosophy of nature that has led to the growth of science, scientific inventions and discoveries leading to the objectification of the world, on the other hand research on the other two philosophical systems have been negligible. Gradually and persistently science has overpowered the philosophy society and language. Along with, the growth of positive philosophy, an outcome of scientific enquiry or philosophy of science has brought disunity in the society with its separation of subjects from the objects, often experimenting through the language of violence. Here we can say, 'violence' or 'disunity' or 'science' that has conquered every aspect of our life including media can only be countered through the language of 'nonviolence'. What we need at this hour is an experiment through the language of 'nonviolence' for unity of the self and unity with others.

\section{Reflections from the North-East India}

In the North-East India, as is the case in the rest of India and the world, conflicts and violence are regular 'incidents', and also 'events'. They are 'incidents', when they are spontaneous, and turn into 'events' when they are organised, managed, created or manufactured as it is in the recent clash between the Bodos and the so called immigrant Muslims of Kokrajhar district in Assam that broke out on July 20, 2012, the violence later spreading to different parts of the country as a result of rumour mongering and hate campaign through the social media and mobile phones. Another such incident is the harassment and manhandling of a girl in Guwahati on July 9, 2012 and its coverage in the TV and its postings in various social networking sites that give a good idea how incidents turn into events through media culture which is often violent. Considering these facts, media in NorthEast, along with the mainstream media (both print and electronic, including social media) has a significant role to play in creating a condition for the restoration of peace which is only possible through nonviolent media coverage of the incidents that are taking place not only in this region but also in different parts of the country.

Over the last few years, Assam has seen many violent incidents, most of them occurring in and around its capital-city Dispur (Guwahati) — such as the incident of mob assault on an Adivasi girl on November 24, 2007, when she was stripped naked in the broad daylight followed by a violent and unethical media coverage of the incident; the serial bomb blast on Oct 30, 2008, and its violent reportage showing the charred bodies and destruction of public property by the angry masses; the violent clash between the police force, and landless people carrying out a rally demanding land rights and its violent coverage in the media. There have been similar other incidents taking place in different corners of the state from time to time. With the help of both print media and nearly a dozen $24 \times 7$ satellite TV news channels which are competing for televisual space, the past incidents/events have got national attention. Further, a healthy base of internet users and social-media activism has taken the issues of north-east to different parts of the country irrespective of their scale and magnitude, affecting people from the North-East residing in different locations of the country. What is observed is that conflict and violence have been the key content among TV news media of Assam, followed by the mainstream media, expanding the horizon of conflict. Both media and the masses are so addicted to a daily dose of violence, that, when there is no such major violent incident, the media turns to petty isolated violence. Sometimes incidents such as a person being beaten by the public for committing a minor theft are shown with all violent aspects. Sometimes it so happens that the public informs the reporters to arrive and take visuals of them punishing a person for committing a minor offence. Aggressive projection of such incidents in the media often results in more violence with a multiplier effect and sometimes miscreants come out openly to assault women and other vulnerable sections with an objective- "violence for more visibility", as it happened in the case of harassment of the girl in Guwahati on July 9, 2012 by a group of men or the assault of a Mizo girl a few years back in Guwahati city by a group of women (my emphasis). Such a phenomenon is often linked with the culture of violence through media including print, TV and the social media. While print media such as newspapers and magazines have furthered the violence with their provocative headlines (often statements) and violent or appealing photographs, television has led the condition of conflict to worse by provoking more violence with its repeated and round the clock coverage. The social media is at its worst in the recent two incidents by taking them to different parts of the country without lapse of time often with violent and provocative comments. Such incidents which are now a regular part of our life and society urge for an introspection of our engagement with media and social space. 


\section{Analysis and conclusion}

If we reflect upon the above mentioned incidents or the violent tendencies, it seems that it has grown out of the disunity of subject and object in both the cases of social practice and media practice. If we take the case of media, it has been violent because it has ignored its roles and responsibility towards the society. Either media has acted with too much of its subjective interference or with too much of objective responsibilities. And in case of individuals - irrespective of sex- a similar kind of disunity is perceptible because they do not know how to condition themselves with the objective realities or how to engage themselves with the changing social and material space.

The subject-object disunity in both media practice and social practice is further affecting our cultural practices leading to a culture of violence. Just as in the case of base-superstructure and material-ideal dualities, media and culture fits into one drawing upon the other. They are interdependent. Media often produces new cultures as pointed out by Theodor Adorno and Horkheimer (Adorno and Max Horkheimer, 1993) who see media as culture industry. But sometimes, cultural values have bearing on the media practices ultimately affecting social practices. Even though media is appreciated for its attributes like freedom, autonomy and pluralism, they are often self contradictory in nature. If we take notice of the recent crisis and movement facilitated by media activism that has led the entire world to a state of anarchy including India, it justifies the inseparable nature of media, culture and society. With its all encompassing character, media has become an essential part of our culture and society. At the same time, media has also formed a culture for itself to function and operate within a specific region or country or state as it is in the case of Assam or India. While on the one hand it unites our culture and society, on the other, it draws boundaries with construction of multiple images, formation of diverse opinions and ideas. The concepts of unity and diversity contradict each other because they cannot exist separately; they have to coexist as without unity there wouldn't be any diversity and without diversity there wouldn't be any unity. As an interface between culture and society, media often affects the public discourse as it is reflected in the form of social practices. But how the media should react to the emerging conditions that come out of such opposing tendencies as in the case of unity in diversity and like many others is a matter of great concern not only for media practitioners but also for media academicians and policy makers as well. Is it through the language of nonviolence or a subject-object unity?

\section{References}

[1]. Adorno, T. W., \& Max Horkheimer. (1993). The Dialectic of Enlightenment. Continuum: New York.

[2]. Appaduari, A. (1990). Disjuncture and Difference in the Global Cultural Economy. Theory Culture and Society, Vol. 7. p. 295-310. SAGE: New Delhi.

[3]. Afanasyev, V. (2006). Marxist Philosophy A Popular Outline. Foreign Languages Publishing House: Moscow.

[4]. Chubais, I. (1990). Dialectical Materialism. Progress Publishers: Moscow.

[5]. Lefebvre, H. (1991). The Production of Space. Blackwell Publishing: Oxford.

[6]. Marcuse, H. (1964). One Dimensional Man. Beacon Press: Boston.

[7]. McLuhan, M. (1964). Understanding Media The Extensions of Man. MIT Press: Massachusetts.

[8]. Williams, R. (1980). Culture and Materialism. Verso: London.

[9]. Williams, R. (1993). Culture and Society. Hogarth Press: London. 